\title{
Research and rationalisation
}

In 1985 the UGC began to reveal the formula which it proposed to use in order to calculate the block grant for each university ('transparency' became one of the managerial watchwords of the late 1980s). About two-thirds of the grant would now depend on criteria related to teaching (student numbers, rather than proven pedagogic excellence), the rest on criteria related to research. It appeared that the Committee intended to divide universities into 'cost centres'; to arrive at a 'resource requirement' for each; to add all of them together; and to make extra allowances for certain unusual items which did not fit into the ordinary departmental framework, such as, in Manchester, the Museum, the Whitworth Art Gallery, and the John Rylands University Library. The grant thus arrived at would be composed of $\mathrm{T}$ for Teaching, $\mathrm{R}$ for Research and S for Special Factors.

On close inspection, $\mathrm{R}$ turned out to be the most elaborate compound, for it would consist of four elements, called SR, DR, CR and JR. SR would depend on the number of staff and of research students. DR would reflect the sum total of the grants obtained by members of a university from the Research Councils, charities which supported research, and other sources. By way of rewarding self-help, the UGC would make the university an allowance equivalent to 40 per cent of this sum. This arrangement echoed the time-honoured 'dual support system', whereby the university provided a well-equipped laboratory and researchers applied to the Research Councils or elsewhere to seek additional finance for specific, expensive projects. CR, the third element, depended on carrying out contract work for industry, business and Government departments: a total of $£ 10 \mathrm{~m}$. would be distributed to universities in proportion to the sums they had raised by this means. They would be expected to charge their clients overheads at a realistic rate, and not to subsidise them out of public money.

Fourth came JR, which was to cause the greatest trouble and anxiety, for it would depend, not on counting bodies or money, but on 
judgement: on the UGC's opinion of a university's recent achievements and future promise in research, as described in its returns and plans. Before long a university's excellence in research would become the clearest indication of its standing and have a strong bearing upon its finances. The quality of each department, as the UGC saw it, would be proclaimed to the world when the results of the UGC's Research Selectivity Exercise were announced. Among the consequences would be elation and humiliation, depression and indignation, guilt and perplexity, at least in the early stages of the operation before the procedures settled down and the results became reasonably predictable. In the 1980 s people could be seen wearing badges which announced 'I Hate J.R.', though doubtless they referred to J.R. Ewing, the villain of the soap opera Dallas, portrayed by Larry Hagman, rather than to the UGC's latest device. Like student questionnaires on teaching, this was loved by those who did well out of it and reviled as a devilish invention by those who did not.

As time passed JR became increasingly important in the algebra of public finance. When the UFC replaced the UGC and declared its hand in 1989, it seemed that the judgemental element in research funding could be expected to grow and that by the mid-1990s it would weigh twice as heavily as SR, which rested on mere numbers. DR - the slice of the grant related to income from the Research Councils - would now disappear from the block grant and be transferred to the Research Councils themselves. They would cover all the costs of expensive undertakings in scientific research, except for the salaries of those involved and the cost of the premises on which the work was done. Costly research in the sciences or social sciences would therefore depend heavily on obtaining the approval of Research Councils for specific projects, and the old system of dual support would be under threat.

Like new arrivals at a posh public school, awaiting initiation into its peculiar vocabulary or its esoteric version of football, fives or lacrosse, academics at Manchester approached with apprehension the task of compiling research plans for the UGC. Clearly there were hidden rules in the game, buzz-words to be learned, fashionable topics to be stressed, ways of impressing panels of judges that could only be picked up by experience. Would the UGC and its collaborators get at the substance of a department's achievement, or would everything depend on the skill with which the department was presented by the compilers of its return, on the wrapping paper rather than the gift? Members of Senate objected to the amateurish methods the UGC 
proposed to use, presumably to save itself time - especially their chairman's request for 'the titles of five books which represent the best and most representative scholarship of each subject group in each university'. It was hard to see how, in an individualistic department, a book could represent anything other than its own author. Addressing Senate in November 1985, the Vice-Chancellor urged those responsible 'to portray a forward-looking and dynamic university, not one dwelling on past successes', and warned that 'there were well-informed people outside the University . . . who were quite capable of matching the University's internal analysis with an external view of its strengths and weaknesses'.

The judgements of the UGC panels were first published in May 1986 and complacently described by Sir Keith Joseph as 'a landmark in university funding' (a Labour spokesman, the Member for Denton and Reddish, preferred to call them 'a landmine under higher education'). To the CVCP Swinnerton-Dyer said that his own Committee had done nothing more than expose their judgements for all to see. 'We do not ask that universities should accept our judgements', he explained; 'they can make and implement their own. But there is hardly a single institution which can say with plausibility: "All our departments are equally strong".' It seemed that the UGC was not presuming to dictate exactly how the block grant should be used, or suggesting in detail how rewards and punishments should be dispensed; a university was entitled to invest in bringing a weak department up to scratch, as well as in encouraging a strong one. John Griffith, Manchester's Chancellor, wrote in his pamphlet The Attack on Higher Education of 'a half-baked exercise purporting to assess research performances in university departments, the arbitrary results of which met with both hilarity and anger, but were deployed by university planners, selectively, to suit their prejudices for the management of cuts'.

Half-baked or not, the exercise pronounced sixteen Manchester cost centres above average and awarded rosettes to eleven departments or subject areas which it regarded as outstanding (these were Clinical Dentistry, Psychology, Physics, Applied Mathematics, Computer Science, Geography, Social Anthropology, Accountancy, Spanish, History of Art, and Drama). Some, such as Physics and Computer Science, had succeeded very well in attracting additional posts in the New Blood and Information Technology initiatives which had followed the 1981 cuts. Accountancy was attracting strong support from the profession. Iconoclasm seemed to be at large, proclaiming to be merely average, 
as though to dispel smugness, certain departments which had once enjoyed a glowing reputation - as had Government under Mackenzie and Finer; History under Tout, Powicke and Namier; and Electrical Engineering under Freddie Williams. Certain areas fared poorly and were declared below average, as were Pharmacology, the Biological sciences, Architecture, Town and Country Planning, and Education. The Arts Faculty did badly, in that only one sizeable department with more than fifteen members, Geography, which was part science and part social science but located in Arts, scored highly in the exercise, whereas the large departments of History and English did not.

Guides for the perplexed were not forthcoming. Judgements were not officially explained, and inquiries produced only polite commiseration from civil servants and bland assurances that the evidence had been 'weighed again and again'. Disappointed departments asked themselves how to improve, whilst cynics urged them to accept that they were merely average and always would be. Had there been enough collective activity, should the department have launched a learned journal, should a major conference be organised, did the professors know enough influential people?

Fortunately, no doubt, a rather more systematic exercise took place in 1989. Departments named the recent publications of each individual member of staff, submitted quantitative evidence of various kinds, and were graded on scales of 1-5. There was some movement both up and down, and History, for example, a department which had lost several of its ablest members to chairs elsewhere, succeeded in improving its reputation and rising to Grade 4, which placed it on a par with a large number of good History departments in the country but did not make it outstanding.

Taken as a whole, the results of both operations were pleasing to Manchester. Using a crude measure - the number of departments regarded as outstanding - it was possible, at least from within, to identify Manchester as the fifth of the large institutions in 1986. No match for Oxford, Cambridge and University College London, it ran closer to Bristol and neck and neck with Edinburgh. In October 1989 This Week published an analysis which suggested that Manchester had maintained this position and was still fifth in the race, so long as one counted only large, wide-ranging institutions (defined as those with thirty-five or more departments or at least twenty-one cost centres Manchester had twenty-six cost centres). Add more compact institutions such as LSE, and Manchester dropped to eleventh place. The average score, on the new 1-5 marking scale, of all Manchester units 
was 3.56 (an Arts undergraduate with an average score of just over 70 per cent in his or her final examinations would almost certainly get a first-class degree, though not a first with distinction). Geology, regarded as merely average in 1986, had now joined Physics and Computer Science at the pinnacle; Social Anthropology had again earned the highest possible rating; and Nursing and Dentistry, rated at 4 , had notched up the highest scores awarded by the parsimonious panels which assessed those disciplines.

Weak departments in vital scientific subjects were likely to attract remedial action and have money thrown at them. In some areas of the University it was possible to improve both performance and image by casting down old-fashioned departmental barriers and abandoning worn-out subject divisions. A traditional way of overcoming such hindrances to progress had been and still was the creation of interdisciplinary centres, which left departments intact but brought together scholars with shared interests to consider common problems. Lawyers, philosophers, theologians and doctors could all profitably discuss medical ethics together. However, where the departmental structure was so obsolete as to block intellectual progress, stronger measures were called for, not only on scholarly but also on economic grounds. For the creation of larger departments, or the absorption of departments into schools with a common administration, would lead to economies of scale - one accounts office, one store, one electronic microscopy unit, one safety officer, where previously there had been several - and to savings of administrative time. Some changes arose from within the University and were prompted by groups of like-minded professors. Others were imposed or encouraged by the UGC, by the subject reviews which it commissioned, and by the transfers of academic staff to Manchester which it brought about.

Far from unexpected was the UGC's lack of enthusiasm for the research performance of Manchester's biological sciences. This was an area of special interest to the Vice-Chancellor. He had already urged remedial action by appointing through the JCUD in November 1983 a working party of seasoned professors, both medical and scientific, who were not themselves biologists, 'to investigate the biological sciences associated with Science and Medicine'. Headed by a Pro-Vice-Chancellor, the physicist John Willmott, the working party held sixteen meetings and eventually reported in June 1985. Pressure to reform came as much from the younger professors within the biological sciences as from without: especially from Maynard Case of Physiology, Michael Grant of Biochemistry, Mark Ferguson of Basic 
Dental Science, and Tony Trinci of Cryptogamic Botany. Ten older professors had retired or left the University in the previous three years, and the way to change seemed clear. A discussion paper, wholeheartedly supported by eleven professors and with reservations by five others, proposed to the Willmott working party the establishment of a new Bioscience Faculty, which would assemble staff at present scattered through thirteen academic departments and two other units (those concerned with Marine Technology and Pollution Research). Some of the departments concerned lay in the Faculty of Science, others in the Faculty of Medicine, and they were physically and intellectually separated in a manner which hindered collaboration.

As Willmott and his colleagues later recognised, some of the existing departments had arisen almost a century before and 'reflected the division of material seen at that time', whereas recent developments in research had cut across those lines. It was no longer fruitful to think of anatomy, bacteriology and virology, biochemistry, botany, immunology, pharmacology, physiology and zoology as if they were separate organisms or distinctive species which could not cross-fertilise each other. Efforts to bring them together in the past had not, however, proved outstandingly successful, as witness a history of the Botany Department, published in the 1990s, which described the all-tootentative attempts of the Departments of Botany and Zoology to come together in the 1960s and 1970s.

Advocates of the new Faculty contended that it would give rise to larger and more effective research groups which could more easily be identified by Research Councils and by 'clinical academic staff and others seeking assistance or collaboration'. Expensive equipment, to be shared by many different users, could be purchased and serviced in a more rational and efficient manner; it would be possible to design a curriculum encompassing all the biological sciences; and the Faculty would be able to organise preliminary training courses on subjects of interest to all postgraduate students - including 'computational methods, statistical analysis, instrumentation, care of animals, information retrieval, report writing', and other matters. One reason for reorganising and concentrating the biological departments was to enable them to 'underpin' clinical medicine, by ensuring that budding doctors acquired a thorough grounding in basic science before they embarked on patient care. 'Clinical medicine', reported Willmott and his colleagues, 'is poised to make major improvements in diagnosis and treatment, based on advances in molecular and cell biology.' This approach appealed to the Vice-Chancellor (at his school, Epsom College, the 
first-year Biology Sixth had been the portal to the more advanced Medical Sixth). However, the idea proved less popular with others, who did not wish to see classical botany and zoology eclipsed by research which was more intimately related to medicine.

Despite these reservations, the Willmott working party rejected the concept of an independent Faculty of Biosciences. To establish one might be to sever these disciplines from clinical medicine and encourage separatists in other parts of the University to demand faculties of their own; received wisdom favoured coalescence into larger units, not fission into smaller ones. Willmott and his colleagues therefore recommended that Biological Sciences should become a section or wing of the Medical Faculty, ranking equally with Clinical Medicine and Dentistry, and endowed, as they were, with a Dean.

By October 1986 staff from ten departments had regrouped into four larger ones, entitled Biochemistry and Molecular Biology, Cell and Structural Biology, Environmental Biology, and Physiological Sciences. Within these departments, research groups and interests were clearly labelled and identified in the University Calendar, such as 'Contractile and Excitable Tissues' (within Cell and Structural Biology) and 'Smooth Muscle' (within Physiological Sciences). Members of old departments were not transferred en bloc into these new units, but redistributed: fourteen botanists, for example, went to Cell and Structural Biology, four to Environmental Biology. Appointments were to be made during the coming session to chairs in Molecular Biology (the most neglected rising subject in the field) and Immunology. The four new departments conferred membership of both the Medicine and Science Faculties.

A semi-official statement in the University's house journal explained the significance of the reforms and extolled the power of the biological sciences to change the world through genetic engineering - 'genes can be purified, sequenced, changed at will, reintroduced into individual cells of all kinds and expressed therein as protein. These advances, together with the development of techniques for culturing cells and the availability of many new and powerful laboratory instruments, give a range of experimental approaches which can be applied to a wide variety of biological problems - from fighting disease to improving the quality of crops ....'.

The original professors' proposal for a Biosciences Faculty had urged the need for 'high-quality saturation publicity in all quarters'. Much was now done to present the new organisation, Manchester's beautified if not yet beatified Cinderella, as one of the University's greatest success 
stories. The interests and achievements of Mark Ferguson provided good copy. While still in his late twenties he had been appointed to take charge of the newly created Department of Basic Dental Science, which, since it was rapidly absorbed into the new school of biology, became the most short-lived unit in the University's history. His own research, on palate development in the embryo, had some popular appeal, especially on account of its connection with alligators. These were 'swamp sophisticates' which had adapted excellently to their environment and combined primitive with advanced features: 'Study of their biology has led to unique insights into the mechanism of sex determination in a wide variety of animals and the developmental causes of cleft palate in man'. Honours rained upon him, conferred by the International Association for Dental Research and by the Royal College of Surgeons. This Week did not fail to comment on his, and the biological sciences', growing ability to attract research money. In 1988 the new school, eager to keep itself before the public eye, launched the Biological Sciences Review, a journal designed to present the latest developments in the subject to A-level and first-year students of biology.

Since the early 1980s there had been talk of reducing the range of activities undertaken by individual universities, and even of depriving the weaker institutions of all funding for research. Whole universities did not in the end suffer such drastic penalties, but the UGC's planners did wish to concentrate certain costly subjects in institutions of their choosing, and to transfer to them staff from other establishments. In pursuit of this aim, the UGC commissioned Sir Ronald Oxburgh, the President of Queens' College Cambridge and future Rector of Imperial College London, to carry out a survey of Earth Sciences departments (those specialising in geology, petrology, mineralogy, and so forth) throughout the country. He at first recommended that departments be placed on three tiers, the first of which would be amply funded for research and the second moderately funded, while the lowest, destined merely to provide support for other scientific subjects, would not receive research money from the UGC.

Oxburgh's stark distinctions were later blurred and the contrasts toned down, but Manchester's Geology Department, skilfully steered by Jack Zussman, emerged with credit and stood to gain large numbers of staff and students. It was placed in Category M1, within a group of six top departments deemed capable of laying on substantial single honours courses and engaging in both teaching and research. ' $\mathrm{M}$ ' indicated that it was 'mainstream', ' 1 ' that it deserved to be generously provided with resources. Subsequently renamed Earth Sciences, the 
Department attracted six new staff by transfer from other universities and three by new appointments; the number of students planned for rose from 141 to 215 , consisting of 156 undergraduates and postgraduates taking taught courses, and 59 postgraduate researchers. Manchester, which had two collections of geological specimens, one in the Department and the other in the Manchester Museum, was designated in 1989 one of the five Collection Centres in the country, together with Birmingham, Cambridge, Glasgow and Oxford. It could now expect to receive items from within an area which included the Universities of Durham, Lancashire, Leeds, Liverpool and Newcastle. As Jack Zussman's eulogist told Senate when he retired in 1989, he had at enormous expense of time and effort contrived a 'bid' which resulted in Manchester receiving more additional resources in his field than did any other university. The effect of the review was to recognise the quality of Manchester's Department as equivalent to level 5 in the ranking system used in the Research Selectivity Exercise.

During its sunset years the UGC conducted, apart from its general surveys, a number of smaller subject reviews whose results proved generally favourable to Manchester departments. From the Dental School through Occupational Health to Sociology and to Social Policy and Administration, most received praise and encouragement, and only Celtic Studies (no longer an independent department) was recommended for closure. Unusually, the University chose to ignore this last piece of advice, for it regarded Celtic Studies as a harmless and inexpensive activity, and thought it good that about seven students a year should continue to be taught Welsh by part-time lecturers.

As it announced in a letter of August 1985, the UGC was inclined to question the efficiency of small departments. These were most likely to be found struggling on in, or on the fringes of, the arts and social sciences, and to occur in such fields as drama, history of art, music, social anthropology, and the history and philosophy of science. Their minimum effective size, in the UGC's opinion, might well range from four to nine full-time members. Below that level they would probably provide little intellectual stimulus and, since they could spare no-one for any length of time, prove incapable of arranging study leave. Transfers to other universities might benefit individuals and create much stronger units elsewhere; Manchester profited from these arrangements in several fields other than Geology. Both its metropolitan status and its proximity to other universities acted in its favour, and it became an importer rather than an exporter of talent in certain fields. Indeed, when Richmond resigned in 1990 it 
was said that in his time thirty academics had chosen to come to Manchester as a result of UGC rationalisation schemes, and only one had wanted to leave.

When a review in 1987 identified the Department of Science and Technology Policy as one of four centres of excellence in the country, some extra staff were close to hand in UMIST, which still had a tiny Department of the History of Science, despite the plans of the former Principal to close it down. Both Middle Eastern and Russian Studies gained from rationalisation exercises and from reports which recognised their practical value, not only for the understanding and interpretation of the contemporary world, but also for the assistance of the business and diplomatic communities. There was some talk of reorganising the existing thirty-six architecture schools in the country into sixteen super-schools, a move which might entail merging Manchester's school with that of the neighbouring Polytechnic, but for the time being nothing came of the idea. On its own initiative, the University performed various other acts of reorganisation, which usually involved mergers between departments or the absorption of small faculties into large ones, minnows swimming into the mouths of whales. Music in 1987 and Theology in 1992 abandoned their status as separate faculties and joined the Faculty of Arts as departments. The days of the oneperson department, a piece which would fit into no existing jigsaw, appeared to be numbered. So were those of the department which existed only as a symbol, and consisted only of one or more honorary lecturers whose main concerns lay elsewhere.

Research in many subjects depended heavily on the approval of the research councils and charities which alone could finance them. Revenue from these sources was important not only for its own sake but for its influence on the University's block grant; making the necessary claims on the grant-giving bodies was an important activity within the Finance Department. The Vice-Chancellor spoke in May 1988 of larger earnings from outside research funding, which had risen in the past four years from $£ 8.5 \mathrm{~m}$. to $£ 15 \mathrm{~m}$. a year. Science and Medicine were generally the big earners, to be especially cherished and encouraged, but the largest grant of all, a sum of $£ 2.8 \mathrm{~m}$., was credited in 1989 to the Faculty of Education. This went to a consortium known as STAIR, headed by Tom Christie, a Senior Lecturer in Education. STAIR, whose name stood for 'Standard Tests and Implementation Research', had made a successful proposal to develop tests for pupils at the end of the first stage of the National Curriculum, on behalf of the School Examinations and Assessment Council. 
Understandably, the University's house magazine gave prominence to large grants for projects which promised to confer generous social benefits. All research appeared to be priced, and there was a danger that research which cost little might seem to be of less value; readers did well to remind themselves now and then that what counted was not so much the extent of the grant as the use to which it was put. Compilers of the magazine seemed surprised at the news that $£ 60,000$ was on its way from the Leverhulme Trust to the Department of Music, to finance over the next five years research towards a monumental edition of the works of Berlioz. The arts were not yet known for great collective enterprises, conducted by teams and involving the employment of research assistants. On average, it was said in 1987, each member of the new school of Biological Sciences had earned grant money of $£ 15,000$ in the first six months of the school's existence.

Much of the research conducted in the University was useful in a direct and obvious sense. Some of it was concerned with the diagnosis and prevention of disease, with the relief of pain and suffering, with the repair of injuries, with the extension of care into the community. Sociologists and members of the Department of Social Administration and Social Policy investigated important social problems, ranging from the social and environmental consequences of open-cast mining in the North West and North East to the amateurish and inconsistent behaviour of magistrates and their fondness for custodial sentences. Educationalists worked on projects designed to promote awareness of economic issues and counter economic illiteracy among schoolchildren aged between about fourteen and sixteen. The new Centre for Ethnic Studies in Education won a grant of $£ 65,000$ to explore the pressing subject of inter-ethnic relationships in secondary schools. The centre for Policy Research in Engineering, Science and Technology (PREST), developed a line in research on research - in determining the value of the costly programmes or institutions operated by other people. For five years the centre was engaged in evaluating an ambitious project based at the Department of Industry and known as the Alvey initiative, from which (see Chapter 7, above) the Department of Computer Science had benefited. This operation cost about $£ 300 \mathrm{~m}$. and was designed to involve academia and industry in exploring several aspects of the development of information technology, defined as 'software engineering', 'intelligent knowledge-based systems', 'very large-scale integrated circuits' and 'man-machine interface'. PREST also assessed the work of the Natural History Museum in South Kensington, by asking who used, and for what purpose, its attempts to classify the vast 
numbers of animals and plants within its walls. Members of the centre helped, by devising, distributing, collecting and analysing over 16,000 questionnaires, to carry out a comprehensive survey of equipment held by universities and polytechnics, with a view to discovering how up-to-date and well maintained it was.

Research in medicine and the life sciences had several particular strengths. The University was said to boast 'the largest concentration of connective tissue work in Europe', which meant research on cartilage, bone, blood vessels and skin, much of it under the direction of Michael Grant, the Professor of Biochemistry, and much of it relevant to the relief of osteoarthritis, heart disease, and some aspects of cancer. The Kay Kendall Leukaemia Fund awarded over $£ 900,000$ to Michael Dexter, of the Department of Medical Oncology, and his research group at the Paterson Institute for Cancer Research at the Christie Hospital in South Manchester. The grant would enable them to construct a new laboratory to explore the formation of blood cells and investigate new methods of treating leukaemia. Mancunion, which seldom took much interest in the scientific work of the University, none the less reported on work being done on the AIDS virus and on a new female contraceptive in the Department of Biochemistry. Members of the Department of Pathology, with the support of the Medical Research Council, brought an electron microscope to bear on the formation of senile plaques in the brain in the early phases of Alzheimer's disease. The North Western Regional Health Authority offered $£ 300,000$ to provide Magnetic Resonance Imaging, an advanced alternative to X-rays, for patients suffering from neurological disorders. Professor Iain Hutchinson, of the Immunology Research Group in Biological Sciences, concerned himself and his colleagues with methods of preventing the rejection of transplanted kidneys. Hope Hospital had the only Accident and Emergency department in the country to be provided with clinical staff who were also senior academics. Hence the new North West Injury Research Centre was well placed in the hospital, and the Centre's director, Rodney Little, a specialist in trauma research, spoke of the wide range of injury victims from other casualty and burns units in the area to whom the Centre would have access. Miles Irving, the Professor of Surgery, mentioned the benefits, including the service to industry, of getting patients back to work as rapidly as possible.

Much of the University's work was concerned with the education of doctors, pharmacists, nurses and even patients themselves, in order to supplement the efforts of the National Health Service and to assist 
in putting Government policy into effect. Its importance was as much social as scientific. Geriatric medicine had long been a speciality of Manchester, and it was concerned with such matters as brittle bones and muscular deterioration, as well as with the even broader subject of decline in the performance of elderly people and their diminishing ability to cope with the problems of everyday existence. Specialists in geriatric medicine helped to educate general practitioners, community nurses and others about the problems of incontinence in old people. Professor Stephen Tomlinson and certain colleagues raised money by appeal to cover much of the cost of opening a new Diabetes Centre in two converted houses in Hathersage Road, an enterprise which involved not only doctors and nurses but also dieticians and chiropodists. It was designed to relieve patients of the grim and tedious experience of queuing for up to three hours in the Manchester Royal Infirmary with, at the end of the long wait for attention, nothing more than a brief consultation, an encounter which would concentrate on finding problems rather than preventing them or educating patients about their condition.

The release of mentally ill, or mentally handicapped, people into the community, created problems for local authorities, and members of University departments undertook to investigate them and make recommendations. University pharmacists helped to address the task of training some 2,700 pharmacists in the region as 'community pharmacists' who would be better equipped to diagnose minor ailments and give proper advice to customers. Karen Luker, a Lecturer in Nursing, won a substantial grant from the Department of Health and Social Security to collaborate with a consultant nephrologist at Withington Hospital and develop methods of training which would enable patients to manage their own portable kidney dialysis machines.

The social as well as the medical aspects of the AIDS epidemic claimed the attention of University researchers. Sue Scott, a Lecturer in Sociology, collaborated with colleagues in the University of London in an inquiry called WRAP (the Women, Risk and AIDS project). This set out to investigate the sexual knowledge and behaviour of British women aged between sixteen and twenty-one and the extent to which they had been affected by the spread of HIV infection. The inquiry would not pay excessive attention to the traditional social and economic classifications of the women involved, but rather to 'the amount of autonomy the women have in their life'.

As the journalist George Monbiot would write some years later, in Captive State: the Corporate Takeover of Britain, until the 1970s and 
1980s British universities had generally fought shy of close engagement with industry - unless, as he might have added, the university could clearly retain the initiative, as in the partnership with Ferranti in the late 1940s, when the engineering firm which constructed the early computers was working to the instructions of a university professor at the behest of the Ministry of Supply. The danger, as Monbiot put it, was that contacts with industry might persuade the universities to "concentrate on immediate technological needs rather than on the more profound scientific questions'. Some members of the University were aware of this danger. Brian Dawson, the Secretary to the Faculty of Science in Manchester, spoke to Mancunion in November 1987 of the fear that too much funding might be directed towards applied research, and suggested that Salford's dependence for more than half its income on research contracts and consultancies was leading to research only in very constricted areas. Manchester's reputation, he said, was, and should remain, in 'research for curiosity's value'. Industry, remarked a student journalist, Naomi Koppel, did not always know what it wanted and was liable to change its mind. But dependence on industry would grow if and when public funding of the Research Councils became inadequate. Already, she had heard, projects rated Alpha by SERC were failing to attract funding.

Should universities move closer to business and industry, would research be subordinated to the pursuit of commercial profits, and would scientists encounter restrictions on publishing some of their results? The Vice-Chancellor rightly warned against involvement in enterprises whose sole purpose was to make money, but some forms of collaboration seemed less dubious. Arguably, there was nothing wrong with making businesses aware of discoveries made in universities, so that they might arrange to develop them if they chose, and certainly no harm in encouraging discussions and exchanges of information between businessmen and academics. These appeared to be the aims of CURID and the Science Park, and there was much talk of working on academic areas which happened to be of 'industrial relevance', but in which 'good, sound, basic science' could still be practised. The Universities of Manchester and Liverpool formulated between them a successful collaborative bid which enabled them to establish in Liverpool an Interdisciplinary Research Centre in Surface Science ('the business of how atoms and molecules intersect with surfaces of metals, semiconductors and oxides'). This appeared to be crucial to developments in the chemical industry, which was one of the country's biggest earners abroad. An endearing photograph appeared of the Vice-Chancellor and Baroness 
Blackstone, the Master of Birkbeck College London, who seemed to be at the controls of a train pulling into St Pancras. Sir Mark wore a hat bearing the slogan 'Universities Work', designed to advertise a new publication of the CVCP describing various industries and services, British Rail among them, which had benefited from university research.

In practice, relations between the University, business and the professions were complex and varied, taking at least eight different forms, apart from exchanges of information and expertise.

First, the University was a customer of industrial concerns, from which it purchased, with financial help from the Research Councils or charities such as the Wellcome Trust, certain highly sophisticated instruments. Among these was the 'mini-supercomputer' supplied by Floating Point System (UK) Ltd. of Warrington in 1988; this was designed to make the calculations necessary for molecular modelling and intended to contribute to such matters as 'rational drug design, catalysis and material science'.

Secondly, having acquired expensive equipment, the University could give scientists in industrial employment access to its treasures and charge them for the privilege of using them - as representatives of ICI, Colgate-Palmolive and the United Kingdom Atomic Energy Authority (UKAEA) resorted to the centralised Electron Microscope Unit at the heart of the Medical School. Since it commanded the most powerful university computer centre in the UK, the University could look forward to exploiting its 'excess supercomputer power' and entering into 'lucrative contracts' with industrial concerns.

Thirdly, it occasionally happened that large concerns made generous gifts to the University, including the wind tunnel which British Aerospace presented in 1990. This was set up at Barton Aerodrome and for a time provided, under contract, testing facilities to the TWR Jaguar Racing Team.

A fourth kind of link began to develop through the professor or senior academic who had considerable experience in business or industry and continued to maintain connections with it after appointment to a University post. New academic types began to appear on the scene and to be greeted with applause. David Warren, who became Professor of Computer Logic in 1985, had founded two years earlier, in the United States, a company called Quintus Computer Systems Ltd., of which he was now a Vice-President. Brian Warboys, who had spent his working life with ICL (International Computers Ltd.) combined an ICL Fellowship with a chair of Software Engineering in the Department of Computer Science. 
Fifthly, there were some fields in which firms sponsored students or took a direct interest in the education of bright young things who might be attracted into their employment. Certain firms were willing to give students in Electrical Engineering problems to solve and projects to carry out; these usually entailed developing under supervision a complicated piece of equipment up to the point at which the students could construct a prototype for production. Designs worked out in the Department under this stimulus included a complex portable computer for analysing digital control systems on board ships. And if engineering firms could help educate students, the University could provide academic direction for engineers working on industrial premises. The Department of Anaesthesia at Withington Hospital undertook to supervise graduate engineers working at Ohmeda, a firm which formed part of the BOC Health Care Group, on the development of new anaesthetic breathing systems which would be widely used in operating theatres and intensive therapy units.

Sixthly, it was possible for intellectual reasons for University groups or units to address themselves to the problems of industrial machinery and industrial buildings. Since 1980 the Wolfson Maintenance Unit had worked closely with the Department of Engineering, and had carried out consultancy work. This involved, among other things, using sophisticated instruments to keep watch over the condition of machinery and to anticipate trouble, by predicting failures before they occurred. Among the Unit's clients was Ford of Europe, which commissioned it in 1986 to conduct a pilot study ranging across seventeen of their plants. In the Department of Architecture, the Architecture for Industry Research Unit, headed by Dr James Harris, investigated the formidable problems faced by British industry in that it had to struggle, to a greater extent than did its leading foreign competitors, with obsolete buildings and overcrowded sites.

A seventh area of collaboration lay in the endowment of chairs and other senior posts by businesses and by successful firms of accountants, consultants and solicitors. Their generosity appeared to provide welcome relief from the bleak and threatening climate of the early 1980s, in which many posts had fallen to the financial axe. There was a price to pay, in the form of suspicion (even in the absence of evidence) that a benefactor would acquire some kind of hold over the University. It was, after all, an axiom of the Thatcher period that no free lunches were ever to be had. Left-wing critics might well suggest that Manchester was in thrall to capitalism, whose philanthropy could never be disinterested. They might seek, or imagine, evidence of pressure to 
produce a certain type of useful graduate, or of expectations that research would be steered in directions useful to business.

However, some departments concerned with vocational training existed almost by definition to serve the needs of the professions and made no secret of the fact. Peat Marwick (later Peat Marwick McLintock, described in 1989 as 'the UK's largest accountancy and management consultancy practice'), endowed two chairs in the Department of Accountancy and Business Finance and also supported a Readership and Senior Lectureship. Herbert Smith, the London firm of solicitors, topped up a lectureship and endowed a chair of Corporate and Commercial Law, their senior partner noting the risk that the legal profession (sometimes said to be approaching saturation in the past) would soon be insufficiently supplied with graduates. David Milman, the senior lecturer appointed to the chair, was co-author of an Annotated Guide to Insolvency Legislation, a work read avidly by accountants; he also became the director of a new Centre for Law and Business. Halliwell-Landau, a Manchester firm specialising in commercial law, funded a new lectureship, sponsored a reading room in the Law Faculty Library, and pledged almost $£ 250,000$ to the Faculty over a period of ten years.

It became known in 1989 that ICI Pharmaceuticals and Glaxo were about to support two new chairs in the Department of Physiological Sciences. ICI's object was, by founding a chair in Molecular Pharmacology, to strengthen the University's work on the design, development and analysis of drugs; Glaxo's, through a chair in Neuroscience, to encourage investigations of the brain and nervous system. In the same year Boots the Chemist Ltd. established a new chair of Pharmacy Practice in the Department of Pharmacy. A British Gas Chair of Urban Renewal arose in the midst of the Department of Architecture. The UGC commended the University for seeking industrial funding for a chair in Occupational Health and raising enough money to support it for seven years.

Some business folk endowed posts which had nothing specifically to do with their own economic interests. John Hinnells, the Professor of Comparative Religion, launched in 1986 an appeal for funds to support a post in modern Jewish studies, thus enabling Manchester to extend its concerns beyond the field of early classical Judaism. From his campaign came a chair which was eventually financed to a large extent by the Alliance Family Trust, David Alliance being the Group Chief Executive of Coates Viyella, which had long had business interests in the region. Here the intention was not to serve the practical 
needs of a particular business, industry or profession, but to enlighten and inform those who would soon become influential professional people. As Professor Hinnells promised, 'we will produce graduates with an informed and sensitive view of Judaism. As they go on to careers in such opinion-forming professions as teaching, the media, the Civil Service and social work, which so many of our students will do, they will be well equipped to counter anti-semitism.'

It was also true that professional or industrial firms were not the only sponsors of chairs in vocational subjects. To mark its own centenary in 1987, the Queen's Nursing Institute endowed the first chair of Community Nursing in the country. This went to Tony Butterworth, originally trained as a psychiatric nurse, who had been a Nursing Officer at Withington Hospital and a Lecturer in Applied Community Studies at Manchester Polytechnic. He had worked with AIDS patients and had helped to develop courses for nurses working with drug addicts and alcoholics.

The last and perhaps most intimate bond with industry grew out of collaboration in the development of new products, the exploitation of inventions. These things could be done either through the University's own company, Vuman, and its subsidiaries, or by entering into partnership with an independent company. Roger Hambleton of Pharmacy, and Edward Duff, the University Research Consultancy Officer, took a prize in an 'academic enterprise' competition set up by the British Technology Group - a reward for their initiative in developing, together with Lantor [UK] Ltd. of Bolton, the device known as the Lantor Cube Engineer's Autoclave Test Pack. This was used to test the hospital machinery which sterilised surgical instruments. By 1989 'industrial collaboration' was far advanced in the physiological sciences, in which area twenty-three joint projects with fourteen different pharmaceutical companies were under way.

It was also possible for the University to work on its own, although its efforts to do so were not always crowned with immediate success. In 1985 the University Council had set up a Committee on Research Exploitation, and this body was to ensure that Vuman, acting as the University's agent, would be the first to assess the commercial potential of University research, to make an initial patent application, and to discuss the matter with possible licensees. Should Vuman not wish to proceed, the Council Committee would decide whether or not to offer the work elsewhere. There was some uncertainty as to whether Vuman ought itself to become involved in manufacturing or in basic development work, designed to bring products to the point at which 
they could be commercially exploited. Any expectations that the company would immediately and consistently record large profits were soon disappointed. Vuman sustained a loss of over $£ 70,000$ in the financial year 1986-87 and made a pre-tax profit of about $£ 60,000$ in 1987-88. But it required heavy initial investment in order to build up its working capital for the purposes of development. The call to put in a further $£ 500,000$ in 1988 prompted questions in Council and requests for more candid financial statements. Seeking to reassure the doubters, the University Treasurer and others urged that Vuman 'represented the public image of the use of the University's expertise' and justified its activity, particularly in the field of lasers, as potentially 'of great value to society in general'.

In 1988-89 Vuman again showed a modest profit, but, like the University itself in the eyes of the UGC, it appeared to have both strong and weak performers. At least for the time being the strength appeared to lie in Medeval and Predictive Control, but the Laser Division, the Delta Division and Vuman Computer Systems Ltd. had failed to meet the high expectations entertained of them. It could then be said that, although the company 'operated within a highly competitive commercial environment where risks were higher and outcomes less certain', a profit had been made and the University had received some royalties. Unfortunately, in the following year Vuman incurred a heavy operating loss of some $£ 230,000$, when even Medeval's profits were falling, and the company was compelled to cut its costs. The loss was partly due to delays in making available commercially a new version of Vuwriter (the word-processing programme for scientists) and to development costs carried by the Laser Division. At this point the Deputy Vice-Chancellor, Sam Moore, who was holding the fort after Mark Richmond's departure, expressed the view that 'Vuman should not be involved in development funding or actual manufacturing, but should rather be a company responsible solely for the exploitation potential of the University's research products, through the activities of licensing and trading'.

The University's reputation for effective research depended to some degree on its ability to supervise postgraduates, and particularly to persuade doctoral students to bring their theses to completion. Only completed works, the visible and tangible products of their labour, solid additions to knowledge and understanding, marshalled on library shelves and properly catalogued for readers to consult, would convince the dispensers of funds that public money was being well spent. Few would be impressed by suggestions that defaulting 
research students had learned a great deal on the way to the nonproduction of their dissertations or by pleas to the effect that the investment in their future had not been entirely lost.

Doctoral students were initially registered and most of them financed for three years of concentrated work on their dissertations, and few of them succeeded in writing up their results within that time. University regulations allowed them to dally for another five years, sometimes more, before presenting their results. Ill-defined expectations and the absence of word limits, particularly in arts subjects, encouraged students to embark on ever more ambitious topics which they could not hope to exhaust. Grants normally ran out after the first three years, students took part-time if not full-time work and the dissertation was driven to the wall. Some blamed chronic poverty, anxiety for immediate employment in order to lead a normal life, mounting disillusionment with the academic world and the evaporation of prospects within it, misguided perfectionism and lack of confidence. All these things tended to deter the less determined students. One thinks of poor Zipser, in Tom Sharpe's Porterhouse Blue, of his unequal struggle with 'The Pumpernickel as a Factor in the Politics of Sixteenth-Century Westphalia', and of all the distractions that overtook him before his untimely death. Real-life Zipsers needed a sense of urgency and rather firmer direction from above.

Postgraduate students and their representatives complained of casual supervision and of the lack of official procedures for complaining about it to anyone other than the errant supervisors themselves. Academics were inclined to blame indiscipline and the absence of organised basic training in the techniques of research. Students supported by the Economic and Social Research Council (ESRC) gave particular cause for concern. By way of a partial remedy the ESRC backed a doctoral training programme organised by Professor Brian Robson of the Geography Department. This scheme, launched in 1985 and drawing on the skills of seventeen departments, endeavoured to provide doctoral students with a sense of structure and purpose during the first year of the three, when they might all too easily drift into uncertainty and isolation.

It was hardly possible to sue defaulting students for breach of contract; they had received grants, not publishers' advances. But, since the ESRC allotted a certain quota of studentships to each department considered worthy to receive them, the Council could apply sanctions against institutions whose students performed poorly and could cast them into limbo until, suitably chastened, they promised to mend their ways. The ESRC expected a certain proportion of its students to 
complete their work within four years and stepped up its demands as time passed. It increased the requirement from a mere 10 per cent in 1985 to 25 per cent in 1986, 35 per cent in 1988 and 40 per cent in 1990, when a hurdle of 50 per cent was in prospect. Early in 1988 the University began to suffer from these measures, in that the ESRC refused to go on supporting certain courses and departments, whilst in 1990 it judged the institution as a whole and found that its overall submission rate was no better than 27 per cent. By way of penalty the ESRC then withdrew all studentships from Manchester for the time being, and it was feared that the consequent fall in student numbers might reduce the University's block grant. This measure bore hard on the Faculty of Economic and Social Studies, which had achieved rates of over 50 per cent but been dragged down by the poor achievements of others. The Faculty could only comfort themselves with the reflection that the Research Council would in future invite universities to nominate departments for recognition and base its calculations only on their performance. It was unlikely that the University would back the weak and inefficient.

By way of concentrating the postgraduate mind, the University began to make its doctoral regulations a shade less indulgent. It reduced from five years to two the period after full-time registration in which Doctor of Philosophy (Ph.D.) students were automatically allowed to submit their dissertations after completing them. After that time they would have to explain themselves at intervals and apply for extensions, although they would be able, if their excuses proved convincing, to continue as doctoral students for another four years.

There was a growing danger that the Faculty of Arts in particular would develop into the University's poor relation. It might come to resemble one of those peripheral provinces, like Catalonia in the old Spanish monarchy, whose inhabitants complained endlessly of their exclusion from the honours and privileges enjoyed by those closer to the centre of royal power and patronage. The arts contributed little to the much-vaunted 'links with industry'; even writing business histories presented certain problems, in that scholars describing recent events might be prevented from publishing their results lest they disclose professional secrets. Engineers and other scientists contributed their consultancy fees to the University's coffers; a member of JCUD once argued passionately that arts authors ought likewise to hand over the royalties (should there be any) of books they had written in the course of duty. Had the University subsidised arts research adequately, the argument might have cut some ice. As it was, most scholarship ran 
at a loss. A complaint of arts academics was that they had to support their research from their own pockets as if it were some form of private self-indulgence, the University entertaining the delusion that they could do it for little or nothing in their ample vacations.

In the aftermath of the second Research Selectivity Exercise in 1989 grievances began to be voiced in the correspondence columns of This Week. Lecturers in Italian, in French and in Turkish complained of having to finance from their own salaries the work they were contracted to do and of having to subsidise their own departments lest these suffer from poor research ratings. They spoke of poor or non-existent allowances for photocopying, of the high cost of materials ordered from abroad by Inter-Library Loans, of the cost of travel to conferences, of the price of stationery, of the need to purchase one's own word processor, of the Inland Revenue's reluctance to allow items of expenditure to be set off against tax. Colin Imber, an expert on the history of the Ottoman Empire, told of the near-impossibility in his situation of obtaining sabbatical leave, and described how, when he had decided to sacrifice 'several thousand smackers' to obtain release to do research in the form of leave without pay, he had been told how lucky he was to be granted such a privilege. A difficulty for the arts was that, unless their topics were of clear economic or social significance, they had no Research Council from which to seek large grants. The British Academy, which administered postgraduate studentships in arts, could offer small grants for travel and other research purposes, and was able to award a few coveted Research Readerships to academics in midcareer. But it was not yet well placed to subsidise research leave on a large scale.

Since 1984 the University had striven to remedy the shortage of research awards in all subjects by providing its own Research Support Fund (there was no particular intention to favour the arts). Sir Francis Graham Smith, the chairman of the committee which administered the fund, felt moved by Dr Imber's lament to give an account of its activity. Since its establishment the committee had received 443 applications and had been able to afford only 53 grants; hence the success rate appeared to be no more than 12 per cent.

Close to hand lay a superb resource for historians, literary scholars in many languages, Hebraists and others. But the John Rylands Library in Deansgate was (or so some critics maintained) in danger of declining into a mausoleum, a depository for a vast but inaccessible treasury of manuscripts and archives which it was unable to sort and list. The Vice-Chancellor told the University Council that on a good 
day the richly appointed but sepulchral building of Basil Champneys might receive five visitors, on a bad day none. Arguably a library which stored items but did not make them available to readers was failing in its duty to the citizens of Manchester, to the University and to the wider scholarly community. This pessimistic view of the Library was not universally shared, but it carried weight among influential people. The subject specialists on the Library staff could not easily be spared to work on the collections, and even if they could their results were unlikely to reach the standard established by the professional archivists whom other institutions employed.

There arose the idea, in itself admirable, of establishing a John Rylands Research Institute which would provide bursaries and fellowships for scholars prepared to work on the Library's collections, with a view both to arranging them and to interpreting their contents. David Miller, the second Deputy Librarian, drew up plans in a paper of 17 November 1986, and the process gathered momentum under his leadership at a time when the University Librarian, Michael Pegg, had fallen gravely ill and was slowly recuperating from treatment. In 1987 the Library Committee and Senate endorsed the project. They were told of proposals to raise funds by publishing facsimiles and microfilms of the Rylands treasures; by appealing to local businesses (which might be moved to give luncheons in these dignified surroundings and make suitable donations in return for the privilege); and by selling so-called 'duplicate copies' of books. Approaches might be made to educational trusts; to the Jewish and Chinese communities; to the French Government, since the Library held on deposit a fine collection of pamphlets relating to the French Revolution; and to the Hellenic Foundation.

Most of these proposals, though optimistic, were unexceptionable. But bitter controversy, damaging to the University's reputation, began to arise over the proposed book sale, for it became clear that what the small circle of librarians working with Dr Miller had in mind was not an auction of recent publications or ordinary nineteenth- and twentiethcentury works. Rather, they were proposing a sale of books published before 1500 , of other early printed books, and of some hugely valuable illustrated works on natural history. These items might be expected to raise between them $£ 1 \mathrm{~m}$. or more, and endow the new Institute with an annual income of some $£ 70,000$. There might be talk of 'duplicates', but could that term be applied to early printed books, and could an edition printed on paper be called a duplicate of a similar edition printed on vellum and prepared for a famous connoisseur? Meeting in October 1987, the Library Committee were warned of the difficulty. In this connection, 
'duplicate' could never mean 'an exact replica'. Before 1801, they were told, 'type was set by hand, text was often proofread and corrected after printing had begun and a variety of different media was used ... the Library had considered [for possible sale] copies which duplicated the text but were not necessarily duplicated in all other respects'. As a writer in the Times Literary Supplement (TLS) subsequently observed, 'The very notion of duplicate books is one which meets with hollow laughter from scholars, bibliographers and collectors. No two copies of early printed books are ever exactly alike: they vary in small but significant ways.' Peter McNiven, a historian and librarian, was to write some years later that the Library laid itself open to charges either of failing to appreciate this fact, or else of trying "to give the impression that "true" duplicates were involved in order to allay legitimate concerns'.

As its defenders maintained, the Library proceeded circumspectly, consulted with interested parties within the University, informed some other libraries of its intentions, and got a mixed reaction from them. On the advice of the librarians immediately involved, the Library Committee determined to put ninety-eight items on sale at Sotheby's on 14 April 1988. Most of these came from two major collections: that of the second Earl Spencer (1758-1834), previously housed at Althorp and purchased by Mrs Rylands in 1892 from his descendant, the fifth Earl, who was then the Chancellor of the University; and that of a versatile Manchester professor, Richard Copley Christie (1834-1901), who had bequeathed his books to the University. Indignant denials greeted the suggestion that the sellers had chosen the best copies and put them up for auction with a view to making the most money. When in doubt, they replied, they had chosen the Spencer volumes, more of which had been cleaned up, freed of marginalia, and rebound. The present Lord Spencer and the present Lord Crawford (the owner of one of the most valuable collections deposited in the Library) were members of the Library Committee and as such party to its recommendations; the involvement of the father of the Princess of Wales increased public interest in the transaction about to take place.

Within two or three weeks of the impending sale it became clear that certain influential figures in the world of libraries and book-collecting had not been persuaded of the arguments for disposing of the books. Among them were Fred Ratcliffe, now the University Librarian of Cambridge, who had helped to bring the University and John Rylands Libraries together in 1972; Lord Crawford, whose family had sold a substantial collection to Mrs Rylands in 1901, and had deposited other holdings in the Library; and Nicolas Barker of the British Library, 
editor of The Book Collector and a member of the mainly aristocratic Roxburghe Club. Letters published in The Times and the TLS accused the University of breaking faith with its benefactors and the people of Manchester, and urged it to cancel the sale. One came from Fred Ratcliffe and several distinguished librarians, together with the Master of Emmanuel College Cambridge and a former Chairman of the Friends of National Libraries. Six members of the Roxburghe Club, of which the second Earl Spencer had been a founder in 1811, swelled the chorus of condemnation and asked: 'Who can imagine the distress which this sale would cause Mrs Rylands?'

Subsequent controversy produced no meeting of minds and no agreement as to Mrs Rylands's likely attitude; everything said about this was speculative. The dispute was represented all too neatly in the University as a contest between bibliophiles and scholars, between hoarders of books and readers of books, as if these were mutually exclusive categories. Was it not possible for scholars to be interested in the history of books, printing and taste? It was probably true, however, that there were many whose interest lay in the essential content of a text, and some who regarded each book as a unique object, which should be considered as a whole, together with its provenance and with the history of the collection to which it had belonged and from which it ought never to be parted. There were also scholars who took an interest in the textual variations of copies of what was essentially the same work. Arguments about duplicates continued and were never settled. There was much dispute about the coherence of Lord Spencer's collection and some impatience with the tendency to regard it as sacrosanct. Had the Spencers themselves ever hesitated to sell books when they found it convenient and what respect had they shown for damaged medieval bindings? Was it true, or was it not, that Lord Spencer had declined a higher offer than that of Mrs Rylands in order to prevent his books from going to America, and was there or was there not a tacit understanding that the collection should always be kept together (it was not kept in one place in the Library)? Surely, said some participants in the debate, Mrs Rylands had believed in a 'dynamic' Library which would be of use to the citizens of Manchester, and she would not now be shocked at proposals to sell a few items in order to make the rest more accessible.

The Library did not fail to cite clauses from legal agreements and bequests, including the agreement drawn up when the University and John Rylands Libraries merged, which authorised the sale of items at the librarians' discretion. Dr Ratcliffe did not dispute the Library's 
legal right to act in such a way, but he questioned its moral right to do so, and argued that the legal provisos (almost obligatory in trust documents) had never been intended to permit the sales of the 'great books' in the Library's collections. These had not been expressly protected because it had occurred to nobody that they could ever be at risk: 'We put our faith in scholarship, not the law'.

Whatever might be said of Lord Spencer (and Nicolas Barker claimed that his collection had a 'historic unity'), Professor Christie had expressed his wishes clearly in the introduction to his catalogue of his books. 'The Collection as a whole will be found to have a uniform aim and a principle of unity pervading it. It has been formed with a view of illustrating the classical Renaissance of Italy and France. I believe that no other Library in England or the Continent contains a more complete collection ...' A fine stained-glass window beside the staircase in the Christie Building depicted the professor, in full academic dress, reading at a desk and flanked by the figures of Erasmus and of Aldus Manutius, the Venetian printer, several of whose books figured in the sale. The Christie Building, which had once housed the Science library, was now an empty shell. Was Christie's collection to be violated and his wishes ignored?

Interviewed years later, in 1999, Dr Ratcliffe said: ' . . . it was totally out of character with Manchester . . . I couldn't believe it at first . . I I was very upset by it because I was the person who'd really persuaded the Rylands and the trustees that this could never happen .... '. The Rylands could, towards 1970, have solved all its financial problems by selling just one book - its copy of the Gutenberg Bible, one of the finest in the world - but had chosen instead to put all its holdings in trust at the University. At the time of the controversy in 1988 Dr Ratcliffe argued that the University ought to have used the investments of the Rylands Library to finance the Rylands Research Institute.

Undaunted and resentful of opposition, the University proceeded with the sale, from which it reaped the unexpectedly large sum of $£ 1,620,000$. Peter Stockham, the bookseller, distributed a mockVictorian penny-dreadful handout to those attending the event, which called it 'A Cruel and Inhuman Murder Committed upon the Body of the University of Manchester'. This Week, which had never echoed the official point of view with greater fidelity, gloated over the proceeds of the sale and dismissed its distinguished critics as ill-informed, without referring to their status and qualifications or answering their arguments. Two members of the Departments of Greek and Latin, Harry Jocelyn and David Bain, rebuked it for insensitivity. Professor 
Jocelyn wrote: 'The vulgar triumphalism of language like "sale of the century" must embarrass even some of those who think the sale justified'. David O'Connor, an art historian, compared the Library unfavourably with the Whitworth Art Gallery, which, being short of space in which to display its fine collections of prints, textiles and wallpapers, had sold no treasures but launched an appeal for funds. Nicolas Barker published in the pages of The Book Collector an outspoken attack on the actions of the librarians responsible, calling the saga of the Rylands 'a story in which stupidity and duplicity go hand in hand'. He professed to see in the affair a reflection of the classic conflict between the landed aristocracy and the rising bourgeoisie, evinced in 'a mean-minded dislike of owning such frankly aristocratic objects'. The wittiest counterblast blew from the PN News, formerly Poetry Nation, in which the poet Michael Schmidt, founder of the Carcanet Press and a Special Lecturer in the English Department, defended the University's position and reflected on the outlook of the fifth Lord Spencer, who, finding himself financially embarrassed, had sold the books to Mrs Rylands rather than dispose of his china.

Much debated was the role of Lord Crawford in the affair. Was he a generous benefactor or an avenging fury, and why, being a member of the Library Committee, had he apparently waited until the last minute to object? Through him had arisen, once more, the possibility of selling a single, immensely valuable book to solve the Library's financial problems. At issue now was not the Gutenberg Bible but Birds of America, the work of the 'American woodsman', naturalist and illustrator, John James Audubon (1785-1851). Lord Crawford had offered the Library his copy of this work on condition that it sold its Audubon instead of the ninety-odd books proposed for Sotheby's; the Audubon would probably have fetched at least as large a sum. But the Library refused the offer, presumably on the grounds that Lord Crawford was only proposing to lend or deposit the book and could have withdrawn it when he chose. After the sale it was he who demonstrated the sanctions in store for libraries held to have broken faith with benefactors. By way of penalty he chose to remove from 'indefinite deposit' in the Rylands his fine collection of materials relating to the French Revolution. It was not among the neglected holdings, for considerable time and money had been spent upon it. The Library had no redress, except to resolve to accept no collections in future without either a guarantee of tenure in perpetuity or a guarantee that on their removal compensation would be paid for the service of having kept them safe and in good order. 
How seriously had the University's reputation suffered? John Zochonis, the Chairman of Council, felt obliged to refute the suggestion that a fit of philistinism had overtaken a great liberal institution. It seemed that the Rylands book sale was being coupled with another pragmatic decision, which concerned Tabley House near Knutsford. The owner of the estate, Lieutenant-Colonel John Leicester-Warren, had bequeathed the house to the National Trust, which was unable to accept it, and it had passed, about 1976, to the University as residuary legatee. The University had decided to lease a large part of the house for 125 years to Cygnet Health Care, a company which proposed to open a home for elderly people. But the University had also agreed to open a museum on the premises, and by way of a curtain-raiser organised an exhibition of paintings from Tabley House, including Turner's 'Windy Day', at a London gallery in Jermyn Street.

In view of the furore it was doubly important to extol the work of the new Institute. There was no question of using the proceeds of the sale for any purpose other than the Institute's support. By the autumn of 1989 the Institute had a staff of six research workers, funded by investment of the proceeds of the sale, and they were working on collections which ranged from the papers of landed families in the North West to the Library's remarkable Hebrew-Jewish collection. Peter Slade, a pioneer of children's theatre, gave his personal archives to the Rylands at Deansgate. A newly formed editorial board had already redesigned the Bulletin of the John Rylands Library, the Library's staid learned journal, in such a way as to bring out every year one issue devoted to the Rylands collections, as well as a thematic issue and a learned miscellany. From time to time new discoveries were reported. A rare book, the Oratio of Alexander Cortesius, printed at Rome in 1483, had come to light by chance among 12,000 uncatalogued items in the Robert Shackleton Collection. Who knew what systematic investigations might reveal?

If the price of liberty had always been constant vigilance, it seemed that the price of survival in the late 1980s was constant surveillance and the price of efficiency constant competition and the publication of results. In return for their employment, still reasonably secure despite the erosion of tenure, academics must now submit to scrutiny, designed in part to establish whether or not they were giving value for money, and in part to identify strengths and weaknesses. Concern with the Research Selectivity Exercises threatened, as time passed, to become obsessive. The fairer these operations aspired to be, the more 
time they consumed and the more mountains of paper they threw up, senior academics spending precious long vacations, not on creativity, but on judging their colleagues. 'Publish or your department perishes' became a nagging admonition, impossible to ignore. However, the improvement of research performance was a legitimate goal. The reorganisation of biological sciences demonstrated the University's ability to reform itself; it provided a model and a precedent for the refashioning of groups of departments into schools in other parts of the University.

One of the University's main intellectual concerns was to preserve a balance between pure science and scholarship, and things of more immediate application, which were both more lucrative and more likely to impress the public and the Government. Developing 'links with industry' was not intended to suggest that the University should be dominated by business ethics and industrial capitalism, although there was a suspicion that it might take on this meaning unless care was exercised. As Sir Mark Richmond explained when reminiscing about the 1980s, 'one of the inexorable things about universities at the moment is that the money-spinners are medicine and science, and that's where the dynamo is'. Hence the need to concentrate on the 'big hitters', whose research ratings and capacity for attracting funding would most affect the University's budget. The consequence of this was, on the part of arts departments, a sense of relief at being left alone, but also one of resentment at being neglected and poorly funded. It seemed hard that one of the more vigorous efforts at selfhelp, the foundation of the John Rylands Research Institute, should have been made in such a way as to bring the University into disrepute and even, in some circles, to impugn its reputation for intellectual honesty and good faith. 